instrument was the main contributor to the quite serious inaccuracies found, he and his co-workers have continued over the greater part of twenty years an advance which has brought them now, using "the most perfect direction-finder in the world", to the estimation of the natural (propagational) limits to the accuracy of practical direction-finding. The greatest individual landmark on this road was the rediscovery and extension of the Adcock system for the reduction of errors due to horizontal electric forces in the received wave front. The National Physical Laboratory may justly be proud of the fact that the prineiple embodied in every good directionfinding installation in the world to-day is due initially to one member of its staff, Adcock, and owes its great development to two others, Smith-Rose and Barfield.

DR. Smith-Rose, whose D.Sc. (London) was conferred for a thesis on direction-finding, was awarded a Student's and a Wireless Premium of the Institution of Electrical Engineers for contributions to its Journal. $\mathrm{He}$ is a member of the British National Committee for Scientific Radiotelegraphy, to which he was appointed by the council of the Royal Society, and has been a prominent participant in all the General Assemblies of the Union Radio Scientifique Internationale, save the first. He participated with the British delegation in the Bucharest meeting of the International Consultative Committee for Radiotelegraphy, is a member of the Wireless Section committee of the Institution of Electrical Engineers, and has rendered valued services as vice-chairman (chairman of the staff side) of the Departmental Whitley Council of the Department of Scientific and Industrial Research.

\section{Geological Society: Medal and Other Awards}

THE following awards of the Geological Society have recently been made: Wollaston Medal to Prof. F. D. Adams, emeritus professor of geology and palæontology in McGill University, for his researches on the Pre-Cambrian rocks and on the influence of high temperatures and pressures on the properties of rocks at great depths in the earth's crust; Murchison Medal to Dr. H. Jeffreys, in recognition of the value of his researches on the constitution and physics of the earth's interior, and in particular of the deductions he had drawn from the analysis of records of distant earthquakes; Lyell Medal to Prof. W. N. Benson, professor of geology in the University of Otago, in recognition of the wide range and excellence of his geological researches, particularly in New Zealand; Prestwich Medal to S. Hazzledine Warren, in recognition of his researches on the geology and archæology of East Anglia, particularly of the Lea Valley; Bigsby Medal to Prof. A. F. Trueman, professor of geology in the University of Glasgow, in recognition of his outstanding contributions to the knowledge of palæontology and stratigraphy, particularly of the Coal Measures and the Lias; Wollaston Donation Fund to I. S. Double, for his work on the petrology of sedimentary rocks, especially the Tertiary rocks of the east of England, the Glacial deposits, the Chalk and the Trias; Murchison Geological Fund to Dr.
A. L. Coulson, in recognition of his geological work in India, especially that concerned with earthquakes and meteorites and the survey of Rajputana; a moiety of the Lyell Geological Fund to Dr. W. Q. Kennedy, for his petrological work, especially in con. nexion with the Tertiary complexes of the Hebrides and the metamorphic rocks of the Western Highlands ; a second moiety of the Lyell Geological Fund to Dr. A. Raistrick, for his researches on the minute structure and constitution of coal, and on the past floras of Britain as revealed by the study of peats.

\section{Sir Isaac Newton's Prisms}

IT is reported from Italy that three optical prisms formerly belonging to Sir Isaac Newton have now found a permanent resting place in the Museum of Treviso. The prisms in question were originally in the possession of Newton's step-niece, Mrs. Conduitt (1680-1739), who spent some fifteen years looking after Newton's house, until her marriage in 1717, to Mr. Conduitt, Newton's successor at the Mint. They were acquired from Mrs. Conduitt by Count Francesco Algarotti, a Venetian nobleman and a prominent figure in London society during the middle eighteenth century. After many changes of ownership the prisms were deposited some years ago in the Treviso Museum, to which institution they were recently bequeathed by the late Prof. Luigi Bailo. Although there seems little doubt that these prisms were at some time associated with Newton, it is not easy to assess what part they played in the fundamental discoveries and subsequent work of Newton on the dispersion of white light. Signor Algarotti was a great admirer of Newton and was the author of "Sir Isaac Newton's Philosophy explained for the Use of Ladies". In the English translation, published in 1739, we learn (vol. 2, p. 70) that Algarotti had found that the prisms available in Italy were unsuitable for repeating Newton's experiments, but that he had been fortunate enough to receive from England some which proved excellent. Later in the same volume (p. 129) we read "I have myself seen the first telescope [Newton's reflecting telescope] . . . preserved in a city of England . . . with this are treasured up those prisms which the first time differently refracted the rays of light in the hands of our great philosopher. . . ." There is no doubt that from about 1664 onwards Newton used many prisms in his experiments and fortunately one of these, at least, is preserved in Great Britain; it was presented in 1927 to the British Museum by the Rev. H. T. Inman, who in a private publication has very carefully traced its descent from Newton. It is made of flint glass, and confirmatory evidence of its date has been adduced from the nature of the glass.

\section{Science and National Defence}

THE Association of Scientific Workers, 28 Hogarth Road, London, S.W.5, has had under consideration the position of science in Great Britain in relation to problems of national defence, and has issued a statement defining its attitude. While the Association regards war as the supreme perversion of science, it 